\title{
Pola Komunikasi Ibu Sebagai Orang Tua Tunggal Dalam Mendidik Anak
}

\author{
Yanti Tayo \\ Program studi Ilmu Komunikasi, Pascasarjana Universitas Islam Bandung, \\ Jl. Purnawarman No. 59 Bandung - 40116 \\ Email: yanti.erwan@gmail.com
}

\begin{abstract}
Since every parent has different communication pattern when they are interacting with their children, this study discusses how communication pattern is constructed by single parents in educating their children. The aims of this study are to find out: (1) how mothers as single parents express education values in the family; (2) the mother's social reality objective as single parent in determining communication pattern for her children; (3) how the mother's communication pattern is internalized by the children; (4) how the communication pattern of mothers as single parents in educating their children form certain behaviors that are shown by the children. Qualitative approach and communication ethnographic method are applied in this study. The study follows Peter L. Berger's social construction theory and Schneider's selfadaptation theory. The result finds out that as single parents, mothers form the communication pattern through the externalization of family education values, social objective reality, and meaningful internalization, while the behaviors shown by the children are altered through their mothers' communication habit.
\end{abstract}

Keywords: single mothers, communication pattern, children.

\begin{abstract}
Abstrak. Penelitian ini membahas tentang pola komunikasi yang dilakukan oleh orang tua tunggal dalam mendidik anak, karena setiap orang tua memiliki pola komunikasi yang berbeda dengan anak. Tujuan dari penelitian ini yaitu untuk mengetahui:(1) ibu sebagai orang tua tunggal dalam mengekspresikan nilai-nilai pendidikan keluarga;(2) realitas sosial objektif ibu sebagai orang tua tunggal dalam menetapkan pola komunikasi pada anak;(3) pola komunikasi ibu sebagai orang tua tunggal diinternalisasi oleh anak;(4) pola komunikasi ibu sebagai orang tua tunggal dalam mendidik anak sehingga membentuk perilaku yang ditampilkan. Dengan pendekatan kualitatif dengan metode etnografi komunikasi. Teori yang digunakan adalah teori konstruksi sosial Peter L. Berger dan teori penyesuaian diri Schneider. Hasil dari penelitian ini, telah diperoleh temuan bahwa ibu sebagai orang tua tunggal, ibu menanamkan pola komunikasi melalui ekternalisasi nilai-nilai pendidikan keluarga, objektif realitas sosial, internalisasi yang dimaknakan dan perilaku yang ditampilkan dibentuk melalui kebiasaan komunikasi ibu pada anak.
\end{abstract}

Kata kunci : ibu tunggal, pola komunikasi, anak.

\section{Pendahuluan}

Orang tua mengarahkan dan mendidik anak dalam bertingkah laku, berbahasa, dan belajar toleransi dengan sesama, hal ini merupakan awal dari didikan orang tua berupa perkataan yang baik dan benar bagi anak sebelum masuk ke dalam lingkungan sosialnya, orang tua seharusnya memberikan pengalaman berkomunikasi yang baik pada anak dalam kesehariannya. Perkataan baik yang terdapat dalam proses berkomunikasi antara orang tua 
dan anak tersebut dapat dijadikan suatu pengalaman yang tersimpan di dalam benak anak, sehingga menjadi suatu 122 pola komunikasi yang membentuk perilaku.

Penerimaan informasi

berkembang sebagai hasil dari pengalaman. Pola komunikasi orang tua kepada anak merupakan sebuah kebiasaan yang dibentuk dalam keseharian dalam keluarga, seperti adanya perbedaan pendapat dengan anggota keluarga adalah pengalaman yang biasa dialami. Pengalaman atau kebiasaan komunikasi adalah pengarah besar yang tidak diragukan lagi pengaruhnya terhadap cara kita memilih, menafsirkan, atau mempertahankan pesan kapan saja. Semua pengalaman yang telah lalu, dan pola komunikasi yang telah terkembangkan oleh kebiasaan, memiliki pengaruh yang pasti terhadap penerimaan pesan (Ruben \& Stewart, 2014:119).

Dalam penelitian ini, peneliti melihat permasalahan pada ibu sebagai orang tua tunggal, ketika seorang ibu ditinggalkan meninggal atau karena perceraian. Banyak masalah penyesuaian diri yang harus dilalui, ketika ibu harus membesarkan dan mendidik anak -anak sendirian, tanpa adanya bantuan dari seorang suami. Hal ini menjadi problem tersendiri, pada saat awal-awal hidup sendiri ibu akan berusaha untuk belajar memahami, belajar untuk mengerti dan berusaha untuk memenuhi segala kebutuhan keluarga. Tentunya semua pola yang terjadi atau terbentuk dalam kehidupan merupakan suatu proses dari pembelajaran dan pengalaman, yang mana pengalaman merupakan pengarah besar yang akan membentuk suatu pola komunikasi yang berbeda pula, tergantung pada pengalaman yang berbeda-beda pada setiap individu.

Masalah umum yang terjadi ketika seorang ibu harus membesarkan dan mendidik anak-anak sendirian, akan terasa pada masalah ekonomi, sehingga ibu dituntut untuk bekerja atau mencari nafkah, hal ini biasa dilakukan oleh suami. Kemudian masalah praktis seperti membersihkan rumah, memasak, belanja dan mencuci pakaian, hal ini merupakan pekerjaan sehari-hari ibu. Adapula masalah psikologis dan emosi pada ibu tunggal, ketika ibu merasa cemas, stres dan sedih dengan berbagai permasalahan keluarga yang harus diputuskan oleh dirinya. Kemudian masalah anak, ibu harus dapat menyesuaikan diri pada anak yang membutuhkan figur ayah, disini ibu akan berusaha mengerti dan memahami semua kebutuhan anak baik dari segi psikologisnya maupun fisik (Hurlock, 1980:311).

Setiap keluarga dari ibu tunggal memiliki pola komunikasi yang berbeda-beda, sebab setiap keluarga memiliki budaya yang telah terbentuk dengan kesepakatan yang dibuat oleh masing-masing keluarga. Hal ini terbentuk dari suatu kebiasaan yang dilakukan dalam keseharian keluarga tersebut, ketika mereka berinteraksi satu sama lain, apa yang mereka lakukan dan hal apa yang biasa mereka komunikasikan. Hal ini didasarkan pada suatu kenyataan adanya perbedaan peran pada ibu yang ditinggal pasangannya (peran yang sebelumnya dilakukan oleh dua orang yaitu dirinya dan pasangannya sementara sekarang hanya seorang diri), Peneliti tertarik untuk melakukan penelitian tentang "Pola Komunikasi Ibu sebagai Orang tua Tunggal dalam Mendidik Anak".

Tujuan penelitian yaitu untuk Mengetahui ibu sebagai orang tua tunggal dalam mengekspresikan nilainilai pendidikan dalam keluarga, realitas objektif sosial dalam menetapkan pola komunikasi pada anak, yang diinternalisasi/dimaknakan oleh anak, dan membentuk perilaku 
komunikasi yang ditampilkan. Teori yang digunakan dalam penelitian ini yaitu teori konstruksi sosial Peter L. Berger, menurutnya tiga hal berjalan secara simultan, artinya ada proses menarik keluar (ekternalisasi) sehingga seakan-akan hal itu akan berada di luar (objektif) dan kemudian ada proses penarikan kembali kedalam (internalisasi) sehingga sesuatu yang berada di luar tersebut seakan-akan merupakan sesuatu yang berada di dalam diri. Keluarga adalah produk individu sehingga menjadi kenyataan objektif melalui proses eksternalisasi dan individu juga produk dari keluarga melalui proses internalisasi.

Teori penyesuaian diri, yang menurut Schneiders (1964), penyesuaian diri timbul apabila terdapat kebutuhan, dorongan, dan keinginan yang harus dipenuhi oleh seseorang, termasuk juga saat seseorang menghadapi suatu masalah atau konflik yang harus diselesaikan. Individu pada kondisi ini individu akan mengalami proses belajar, belajar memahami, mengerti, dan berusaha untuk melakukan apa yang diinginkan oleh dirinya, maupun lingkungannya. Artinya, individu perlu mempertimbangkan adanya normanorma yang berlaku di lingkungan dalam memenuhi kebutuhannya. Hal ini dilakukan dengan tujuan untuk menyelaraskan pemuasan kebutuhan diri dengan situasi lingkungan sehingga tercapai suatu integrasi dan keseimbangan.

\section{Metode}

Dalam penelitian ini, peneliti menggunakan metode penelitian kualitatif yang mana proses penelitian dan pemahaman yang berdasarkan pada metodologi yang menyelidiki suatu fenomena sosial dan masalah manusia. peneliti memilih penelitian kualitatif karena masalah penelitian ini yaitu untuk mengetahui bagaimana pola komunikasi ibu sebagai orang tua tunggal dalam mendidik anak. Peneliti memilih penelitian kualitatif karena hal yang akan diteliti membutuhkan analisis yang mendalam mengenai penyesuaian diri ibu sebagai kepala keluarga sekaligus sebagai orang tua tunggal. Dalam penelitian ini kasus tidak dapat diukur menggunakan angka namun harus dikaji menggunakan ukuran kualitas.

Pendekatan dalam penelitian ini adalah etnografi komunikasi, karena Etnografi komunikasi mengfokuskan penelitiannya pada perilaku-perilaku komunikasi yang melibatkan bahasa dan budaya. Etnografi komunikasi termasuk kedalam penelitian (berparadigma) interpretif atau kualitatif. Dalam penelitian ini, peneliti melakukan pendekatan dengan studi etnografi komunikasi dari Dell Hymes, yang mana dalam etnografi komunikasi menemukan aktivitas komunikasi, sama artinya dengan mengidentifikasikan peristiwa komunikasi dan atau proses komunikasi melalui pola komunikasi ibu tunggal dalam mendidik anak. Bagi Hymes, tindak tutur atau tindak komunikatif mendapatkan statusnya dari konteks sosial, bentuk gramatika dan intonasinya. Sehingga proses atau peristiwa komunikasi yang dibahas dalam etnografi komunikasi adalah khas yang dapat dibedakan dengan proses komunikasi yang dibahas pada konteks komunikasi yang lain (Engkus, 2008:41). Subjek penelitian dalam penelitian ini adalah:

1. Perempuan yang menjadi ibu tunggal karena kasus perceraian atau ditinggal wafat oleh suaminya

2. Menjadi ibu sebagai orang tua tunggal. Usia menjadi orang tua tunggal minimal lima tahun. Hal ini didasarkan pada teori 
Pickhardt (1996), dimana proses pemulihan dan penyesuaian ibu tunggal untuk mampu bangkit dari keterpurukan pernikahan setelah dua tahun lamanya. Hal ini berhubungan pengalaman eksistensi individu yang mengalami kehampaan, kecemasan atas perpisahan atau kesendirian yang sebelumnya tidak pernah diharapkan saat pasangan suami istri dalam menjalani penikahan dan membina keluarga.

Hal ini tergantung dari proses penyesuaian diri dari ibu tunggal tersebut, menurut Santrock, "penyesuaian diri terhadap kematian dan perpisahan seseorang dapat dialami secara berbeda tergantung pada keadaan sosial budaya setempat". Penyesuaian diri seseorang terhadap kematian dan perpisahaan dipengaruhi oleh budaya tempat ia tinggal, dengan adanya bantuan keluarga dan teman yang dapat menolongnya (Berk, 2012: 331). Dalam hal ini peneliti menentukan lima tahun sampel hidup sendirian, sebab proses penyesuaian diri setiap orang berbeda dalam mengatasi stres, dan hal ini dianggap peneliti sudah cukup bagi sampel untuk diteliti, sehingga hal tersebut dapat digali secara mendalam melalui wawancara dan observasi peneliti. Objek penelitian di dalam penelitian ini adalah "Pola Komunikasi" yang dijalankan oleh ibu sebagai orang tua tunggal dalam mendidik anak.

3. Dua orang ibu sebagai orang tua tunggal yang bekerja dan memiliki anak.

Penelitian yang mengambil judul "Pola Komunikasi Ibu sebagai Orang Tua Tunggal Dalam Mendidik Anak“ dilakukan di Kota Bandung, Jawa Barat. Dalam penelitian ilmiah diperlukan sumber data agar diperoleh kelengkapan informasi. Menurut Lofland dan Lofland dalam Moleong, (2000: 112) yang mengatakan "sumber data utama dalam penelitian kualitatif ialah kata-kata, dan tindakan selebihnya adalah data tambahan seperti dokumen dan lain-lain".Sutopo (2000: 50-54) menjelaskan, "Sumber data dalam penelitian kualitatif berupa narasumber (informan), tempat/ lokasi, benda, beragam gambar, rekaman, dokumen dan arsip".

Creswell telah mengemukakan tiga teknik utama pengumpulan data yang dapat digunakan dalam studi etnografi komunikasi yaitu observasi partisipan, wawancara mendalam dan telaah dokumen. Analisis data dalam penelitian kualitatif dilakukan pada saat pengumpulan data berlangsung dan setelah selesai pengumpulan data dalam periode tertentu. Untuk mendapatkan data yang objektif dalam pengumpulan data., maka seorang peneliti harus melakukan teknik analisis data. Moleong (2000: 103) menjelaskan "analisis data adalah proses mengorganisasikan data dan mengurutkan data ke dalam pola, kategori dan satuan uraian dasar, sehingga dapat ditemukan tema dan dapat dirumuskan hipotesis kerja seperti disarankan oleh data". Teknik analisis data merupakan langkah untuk memperoleh hasil penelitian, lalu data dikerjakan sedemikian rupa sehingga dapat menyimpulkan persoalanpersoalan yang ada dalam penelitian ini. Sedang menurut Miles dan Huberman dalam Sutopo (1996 : 82), menyebutkan "dalam proses analisis terdapat tiga komponen yang harus benar-benar dipahami oleh setiap peneliti kualitatif.

Ketiga komponen tersebut adalah 1. reduksi data, 2. sajian data, 3 . penarikan kesimpulan atau verifikasi. 


\section{Temuan dan Pembahasan}

Deskripsi hasil dan analisis penelitian dimaksudkan untuk menyajikan data yang dimiliki sesuai dengan pokok permasalahan yang akan dikaji pada penelitian ini yaitu pola komunikasi ibu sebagai orang tua tunggal dalam mendidik anak, di Kota Bandung Jawa Barat, dijelaskan tentang ibu dalam menjalankan peran dan fungsi baru yakni sebagai orangtua tunggal dan kepala keluarga didalam keluarga dan kehidupan bermasyarakat.

Tabel 4.1

Profil Key Informant dilihat dari : nama, usia, media, masa kerja, kata kunci, dan pendidikan

\begin{tabular}{|c|c|c|c|c|c|c|}
\hline No & Nama & Usia & Media & \begin{tabular}{|l|} 
Masa \\
Kerja
\end{tabular} & Kata Kunci & Pendidikan \\
\hline 1 & IbuVie & 41 thn & $\begin{array}{l}\text { Hp, Radio, } \\
\text { televisi, } \\
\text { intemet }\end{array}$ & 20 thn & $\begin{array}{l}\text {-baik } \\
\text {-pendiam } \\
\text {-ramah } \\
\text {-sabar } \\
\text {-penyayan } \\
g\end{array}$ & \begin{tabular}{|l|} 
D3 \\
sekretaris \\
Aryanti
\end{tabular} \\
\hline 2 & IbuRn & 54 thn & $\begin{array}{l}\text { Hp, Intemet, } \\
\text { televisi, radio }\end{array}$ & 29 thn & \begin{tabular}{|l}
-semangat \\
-kerja \\
keras \\
-baik \\
-perhatian \\
-tegar \\
-tegas
\end{tabular} & $\begin{array}{l}\text { S1 } \\
\text { komunikasi } \\
\text { UNPAS }\end{array}$ \\
\hline
\end{tabular}

Komunikasi yang dilakukan ibu tunggal berdasarkan hasil pengamatan dan kesempatan observasi yang dilakukan peneliti, terlihat sangat jelas bahwa seorang ibu tunggal sangat perhatian pada anaknya. Berdasarkan pengamatan peneliti, interaksi yang dilakukan sangat intens atau sering, hal ini dilakukan seorang ibu tunggal karena rasa sayang yang berlebihan, dikarenakan ibu tunggal mempunyai kekhawatiran akan kehilangan. Sehingga membentuk suatu peristiwa komunikasi yang khas, berdasarkan pengamatan di lapangan, ibu tunggal sering melakukan komunikasi untuk bertanya pada anak antara satu sampai dua jam sekali, jika anak-anak tidak ada dirumah kecuali berada di sekolah. Dalam peristiwa komunikasi terbentuk komponen bahwa ibu tunggal memiliki kekhawatiran yang berlebih yang mendasari perilaku komunikasi mereka, dan yang kedua, bahwa ibu tunggal memiliki harapan dalam mendidik anak, dengan harapan menjadi anak yang baik dan pintar. Hal ini dianggap dapat berpengaruh pada kehidupan sosialnya kelak.

\section{Komponen-Komponen Komunikasi Ibu Tunggal dalam Mendidik Anak}

Sesuai dengan analisis peneliti, bahwa pola komunikasi dibentuk dari hubungan dan fungsi komponenkomponen komunikasi, dari suatu peristiwa komunikasi. Komponen komunikasi ini akan dipahami dengan baik melalui penjelasan mengenai ciriciri umum perilaku komunikasi ibu tunggal dalam mendidik anak, berikut adalah beberapa ciri-ciri umum yang ditemukan di lapangan tersebut:

1. Komunikasi sering dilakukan, antara ibu dan anak, antara ibu dan teman

2. Jarak waktu berkomunikasi berkisar 1-2 jam perhari, kecuali sedang bersekolah.

3. Kondisi duduk selalu berdampingan bila sedang santai, atau pada saat waktu berlibur.

4. Jika sedang marah kondisi duduk berhadapan

5. Menetapkan jam malam untuk anak-anak, tidak lebih dari jam 9-10 malam

6. Bahasa komunikasi menggunakan bahasa indonesia

7. Intonasi suara tinggi jika sedang marah

8. Intonasi suara sangat rendah ketika berbicara normal 
9. Bentuk pengawasan terhadap anak sangat ketat.

10. Kekhawatiran yang berlebih

11. Selalu berbicara dengan tatap muka, dan dengan tatapan mata

12. Selalu terlihat perilaku non verbal, seperti memeluk dan mencium

13. Berdiskusi sangat sering dalam keseharian

14. Pengawasan melalui hape untuk berkomunikasidengan intensitas tinggi, dan cctv

15. Memberi contoh, berupa perilaku ketika beribadah ( non verbal)

16. Tidak banyak mengekspresikan kasih sayang secara verbal, namun non verbal dengan sentuhan, atau perhatian dalam keseharian. Contoh ketika membangunkan tidur sebelum subuh, mencium kening dan menepuk-nepuk badannya.

Penggunaan kalimat sederhana dalam berkomunikasi untuk tujuan membiasakan anak dalam mengingat pesan yang disampaikan, kata "hatihati" sangat sering di dengar peneliti ketika sedang di lapangan. Komunikasi yang khas dalam sebuah kalimat yang tidak lengkap, merupakan kalimat yang terdengar biasa dilakukan. Berikut adalah beberapa contoh kalimat yang peneliti temui selama penelitian berlangsung:

\begin{tabular}{ll}
\hline & Hati hati ya \\
\hline & Dimana? \\
\hline & Sama siapa? \\
\hline & Ada acara apa? \\
\hline & Pulang jam berapa? \\
\hline & Jangan pulang malam- \\
& malam \\
\hline$\quad$ Jangan lupa shalat \\
Penggunaan kata-kata diatas, \\
dikomunikasikan secara tatap
\end{tabular}

muka dengan anak-anak ketika bertemu dirumah atau melalui Line jika sedang berada di luar rumah, hal ini merupakan komunikasi yang biasa dilakukan. Dalam analisis penelitian yang akan dibahas, peneliti akan membahasnya sesuai dengan konsep pertanyaan penelitian yang terdiri dari empat pertanyaan penelitian, yang ditinjau dari peristiwa komunikasi, tindakan komunikasi dan situasi komunikasi yang berdasarkan nilai-nilai, pengetahuan, afeksi dan perilaku.

Pada saat melakukan observasi juga ditemukan penggunaan kata sederhana ketika ibu tunggal merasa tidak setuju dengan perilaku anak, pemakaian kata juga digunakan berupa panggilan yang khas untuk anak, katakata tersebut sebagai berikut:

Panggilan "sayang", seperti kaka sayang, ade sayang

Kata ketika sedang kesal, " ibu tidak suka”!, kata ini diucapkan oleh ibu Rn ketika ibu tidak suka dengan perilaku anak, intonasi tinggi, suara tegas dan tatapan mata tajam.

Kata berikut: "ih kamu mah", kata ini sering diungkap ibu tunggal Vie, dengan dialek sunda dan bahasa indonesia, suatu logat yang menjadi khas, intonasi tinggi, tatapan mata dan raut muka yang menandakan

ketidaksetujuan pada anak.

Penggunaan Line (ketika mengirimkan pesan singkat pada telepon genggam) sering dilakukan dengan memberikan tanda hati 
atau dengan kata "love $u$ " pada akhir kalimat di Line.

\section{Ibu sebagai orang tua tunggal dalam mengekspresikan nilai-nilai pendidikan dalam keluarga}

Sesuai dengan pengamatan yang dilakukan, pada pertanyaan penelitian yang pertama, peneliti berusaha mengamati ekspresi komunikasi ibu tunggal secara verbal dan non verbal pada anak dalam aktivitas komunikasi, yang dimaksudkan dengan aktivitas komunikasi yaitu suatu kegiatan komunikasi yang terdiri dari peristiwa komunikasi dalam keseharian, dengan mencari tujuan komunikasi, bahasa, intonasi, gerakan, adapun tindak komunikasi yakni berupa pernyataan, perintah, atau perilaku non verbal, serta adanya situasi komunikasi yang merupakan konteks dari komunikasi. Ibu tunggal dalam realitas keseharian berusaha untuk menanamkan nila-nilai pendidikan keluarga pada anak, dengan cara memberi batasan seperti normanorma atau aturan-aturan yang sering terucap dari ibu tunggal, menurutnya itu dilakukan agar anak mengerti bahwa ada hal yang baik dilakukan dan tidak boleh dilakukan.

Gambar $\quad 1 \quad$ berikut menggambarkan bahwa ibu tunggal dalam pola komunikasinya memberikan aturan, norma dan kedisiplinan yang mana hal tersebut merupakan bentuk dari nilai-nilai pendidikan yang di ekspresikan ibu tunggal yang dilakukan secara berulang melalui suatu kalimat yang menjadi kebiasaan atau suatu aturan keluarga untuk membentuk anak yang disiplin, rajin beribadah, bangun pagi dan giat belajar, gambaran tersebut menjadi sebuah model pola komunikasi yang telah dituangkan dalam sebuah gambar seperti di bawah ini, melalui hasil temuan wawancara ibu tunggal dan merupakan hasil temuan dari penelitian ini, dengan tujuan memberikan gambaran bahwa ibu tunggal membuat suatu pola komunikasi berdasarkan keinginannya membentuk suatu perilaku anak yang positif melalui suatu aturan, norma dan kedisiplinan berdasarkan nilai-nilai pendidikan keluarga.

Gambar 1 berikut adalah model pola komunikasi ibu tunggal dalam mengekspresikan nilai-nilai dalam keluarga

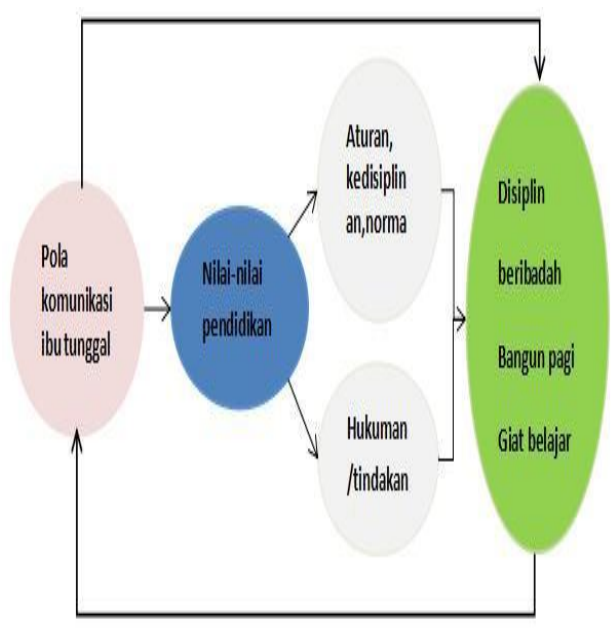

Gambar 1. Model Pola Komunikasi Ibu Tunggal dalam Mengekspresikan

Nilai- Nilai Pendidikan Keluarga

Sesuai gambar di atas, dapat terlihat bahwa pola komunikasi ibu tunggal yang menanamkan nilai-nilai pendidikan keluarga menerapkan aturan, norma dan kedisiplinan, dengan adanya hukuman atau tindakan yang dilakukan ibu tunggal, dengan tujuan membentuk anak yang berperilaku disiplin, rajin beribadah, dapat bangun pagi, dan giat belajar. Nilai-nilai dan aturan dapat membentuk anak sesuai dengan harapan ibu tunggal, melalui suatu pola komunikasi yang dibangun atau dibentuk ibu tunggal. 


\section{Realitas Sosial Objektif Ibusebagai Orang Tua Tunggal dalam Menerapkan Pola Komunikasi pada Anak}

Menurut pengamatan peneliti, ibu tunggal berusaha untuk dapat bertahan dengan bekerja dan berusaha membesarkan, mendidik anak agar dapat hidup di dunia nyata, lingkungan yang akan membuatnya melihat kenyataan yang ada. Realitas sosial objektif adalah suatu kenyataan dimana individu berada pada lingkungan sosial yang apa adanya, dan semua itu dapat dikonstruksi berdasarkan pada pengetahuan, seberapa besar pengalaman, pendidikan, dan seperti apa lingkungan yang membangunnya.

Berdasarkan hasil temuan di lapangan, peneliti melihat ibu tunggal membuat suatu pola komunikasi yang didasari oleh kenyataan atau realitas sosial yang dirasakannya. Ibu tunggal berusaha membesarkan dan mendidik anak dengan harapan dan keinginan yang besar, agar anak dapat tumbuh sebagai seorang anak yang diharapkan sesuai dengan realitas yang dimilikinya.

Gambar 2 berikut merupakan model pola komunikasi, berdasarkan pertanyaan penelitian yang kedua yaitu Realitas sosial objektif ibu sebagai orang tua tunggal dalam menerapkan pola komunikasi pada anak.

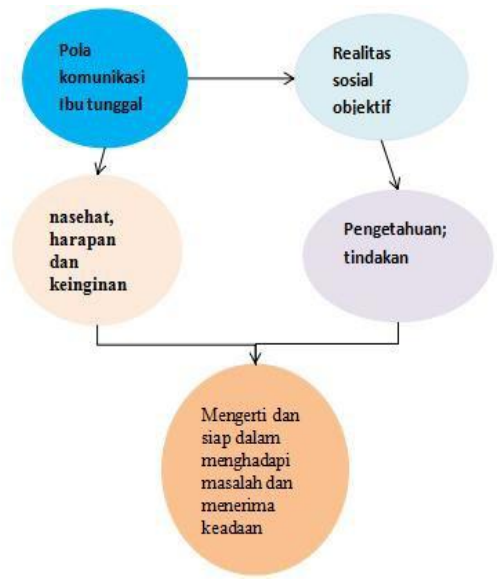

Gambar 2. Model Realitas sosial objektif ibu sebagai orang tua tunggal dalam menerapkan pola komunikasi pada anak

\section{Pola Komunikasi Ibu sebagai Orang Tua Tunggal yang Diinternalisasi /Dimaknakan oleh Anak}

Berdasarkan pengamatan peneliti, ibu tunggal memberikan kasih sayang dan perhatian pada anak setiap waktu dari mulai bangun tidur hingga menjelang tidur malam, kebutuhan anak dalam seharinya selalu dipenuhi dari mulai makan, minum, bekal, sentuhan, ungkapan sayang, baju, sepatu, sampai hal terkecil pun selalu diungkapkan oleh ibu tunggal. Kata terakhir yang peneliti sering dengar ketika anak akan meninggalkan rumah yaitu " awas ada yang ketinggalan", "hati-hati di jalan".

Tugas ibu tunggal dari awal anak bangun tidur sampai pergi sekolah pun sepertinya sudah banyak, setelah itu ibu tunggal bersiap diri untuk bekerja mencari nafkah untuk memenuhi kebutuhan hidup keluarganya. Tidak hanya kebutuhan jasmani yang harus dipenuhi ibu tunggal namun juga dari segi psikologis, seorang anak harus dapat merasakan perasaan nyaman dan aman dalam keluarga, ditambah lagi ketika mereka merindukan sosok ayah, seorang ibu tunggal harus mampu berperan sebagai seorang ayah bagi anaknya.

Berdasarkan pengalaman peneliti, ibu tunggal berusaha untuk membuat anak mereka memaknakan semua perhatian dan kasih sayang yang diberikannya, dengan cara memberikan sentuhan, pelukan, ciuman, pegangan tangan, memberikan sandaran yang hangat, kadang menyuapinya disaat anak sedang sakit dan perilaku non verbal lainnya yang berupa ungkapan rasa sayang ibu tunggal pada anak. Adapun cara lain yang biasa dilakukan 
jika tidak dapat bertemu karena kesibukannya, ibu tunggal selalu mengirimkan pesan singkat melalui hp dengan gambar-gambar emoticon gambar cinta, atau tulisan "love $u$ ", untuk menyatakan bahwa ibu tunggal sangat mencintainya.

Kebutuhan akan rasa sayang dan perhatian ibu tunggal sangat dimaknai oleh anak, menurut kesimpulan peneliti setelah mendapatkan temuan di lapangan, seorang ibu tunggal menerapkan pemaknaan pada anak melalui pola komunikasi yang dilakukan dalam keseharian, kebutuhan afeksi akan rasa sayang dan rasa nyaman seorang anak dilakukan melalui kata-kata atau secara verbal maupun secara non verbal yang berulang dan sering di ungkapkan, secara konsisten dilakukan ibu tunggal agar pemaknaan pada anak dapat tertanam dalam pikiran dan dirasakan oleh anak. Sebagai seorang ibu tunggal semua usaha telah dilakukannya, termasuk membagi waktu antara anak dan bekerja untuk mencari nafkah, untungnya ibu tunggal dapat memberikan kebutuhan anak secara lahir maupun bathin, sehingga mereka menjadi anak-anak yang memiliki rasa percaya diri, bahagia, menghargai orang lain, dan bergaul dengan baik.

Jika secara psikologis kebutuhan anak telah terpenuhi, maka perilaku anak akan tampak sehat atau normal, anak akan terlihat murah senyum, bahagia, terbuka, mudah bergaul dan disayangi teman-temannya. Sebaliknya jika kebutuhan psikologis anak tidak terpenuhi, maka anak akan terlihat murung, anti sosial, tidak percaya diri, tertutup dan tidak mudah bergaul. Itulah kesimpulan dari peneliti setelah mengamati pemaknaan anak pada pola komunikasi ibu sebagai orang tua tunggal.

Model pola komunikasi ibu
sebagai orang tua tunggal
diinternalisasi/ dimaknakan oleh anak,

seperti yang terlihat pada gambar 3 dibawah ini:

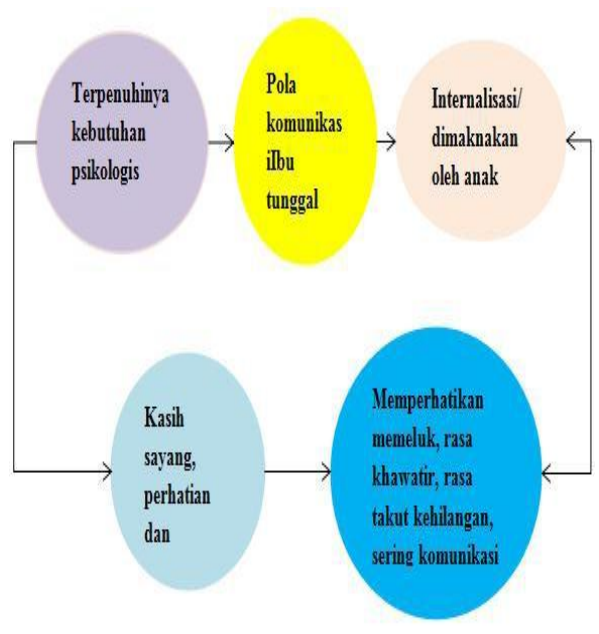

Gambar 3. Model pola komunikasi ibu sebagai orang tua tunggal diinternalisasi/ dimaknakan oleh anak Ibu tunggal

beranggapan bahwa terpenuhinya kebutuhan psikologis anak yaitu adanya kasih sayang, perhatian, dan sentuhan, sehingga ibu tunggal membentuk suatu pola komunikasi yang dapat dirasakan anak, dengan cara ibu tunggal memperhatikan, memeluk, merasa takut kehilangan dan khawatir sehingga memberi perhatian lebih pada anak, dan sering melakukan komunikasi untuk menenangkan dirinya bahwa anak dalam keadaan aman, dan terpenuhi kebtuhannya.

\section{Pola Komunikasi Ibu sebagai Orang Tua Tunggal dalam Mendidik Anak sehingga Membentuk Perilaku Komunikasi yang Ditampilkan}

Peneliti melakukan pengamatan selama beberapa hari pada ibu tunggal, dan peneliti banyak mendapatkan temuan tentang pola komunikasi ibu tunggal, dari kata-kata ibu tunggal yang peneliti dapatkan tidak terlalu aneh dan seperti biasa untuk didengar, namun 
pola yang terbentuk sangat berbeda, ketika ibu tunggal melakukannya secara berulang, kata-kata sederhana dan singkat saja dapat membuat anak memaknainya secara mendalam. Dalam pengamatan peneliti, ibu tunggal berusaha mendidik anak dengan cara yang berbeda-beda, baik secara verbal maupun secara non verbal. Disini terlihat bahwa ibu tunggal perlu memberikan ketegasan, kesabaran, menjadi role model atau contoh, dan turut menjadi teman di lingkungan mereka.

Berdasarkan dari pengamatan peneliti, ketegasan yang dimaksud peneliti yaitu ketika anak merasakan apa yang membuat ibu tunggal "diam" atau "marah", dengan intonasi suara yang tinggi dan bahasa pernyataan yang tegas dan raut muka yang seriusdiikuti tatapan mata yang tajam, hal itu dapat membuat anak mengerti bahwa hal yang membuat ibu diam karena marah, tidak akan dilakukan kembali. Berikutnya tentang kesabaran, dimana ibu tunggal harus dapat berusaha dengan sabar dalam mendidik anak, jika dilihat dari kesibukan dan kurangnya waktu untuk memikirkan dirinya sendiri. Kesabaran mengandung arti datar, intonasi suatu kalimat pernyataan terdengar enak didengar, ringan tidak ada beban, hanya harapan dari suatu kesabaran sangat dalam maknanya. Ketika dihadapkan dalam suatu masalah yang sulit ibu tunggal pecahkan, ibu tunggal selalu tegar dan menyelesaikannya dengan baik. Pengamatan berikutnya dari peneliti adalah ketika melihat ibu tunggal berusaha untuk menjadi role model atau contoh yang baik bagi anakanaknya.

Gambar di bawah ini merupakan sebuah model yang dibuat peneliti berdasarkan temuan dari hasil wawancara dua ibu tunggal. Pola komunikasi yang dibentuk ibu tunggal melalui cara mendidik, pengawasan dan seringnya berkomunikasi, memiliki tujuan agar anak dapat menampilkan perilaku dan mengerti bahwa dalam menjalani kehidupan ini, ada hal yang perlu dipelajari anak bahwa ibadah itu wajib, tahu akan baik dan buruk, memiliki kedekatan dengan orang tua, selalu berdiskusi, dan patuh dengan apa yang diterapkan oleh ibu tunggal.

Gambar berikut adalah model pola komunikasi yang ditemukan peneliti di lapangan, sesuai dengan pertanyaan penelitian ke empat yaitu pola komunikasi ibu sebagai orang tua tunggal dalam mendidik anak, sehingga membentuk perilaku komunikasi yang ditampilkan. Pada gambar 4 berikut merupakan gambaran pola komunikasi ibu tunggal dimana pola yang diterapkan dengan cara mendidik, memberikan pengawasan dan sering berkomunikasi adalah bentuk dari keinginan ibu tunggal dalam membentuk suatu perilaku yang membuat anak menjadi mengerti ibadah itu wajib dilakukan, mengetahui baik dan buruk, sering berdiskusi, sangat dekat dengan keluarga, sering bercerita dan patuh pada ibu tunggal. Seperti terlihat pada gambar 4 berikut ini:

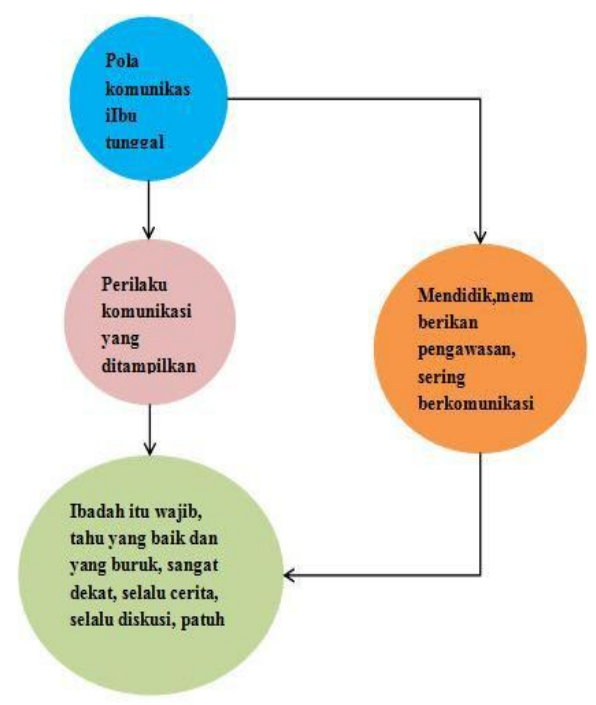

Gambar 4. Model pola komunikasi ibu sebagai orang tua tunggal dalam 
mendidik anak, sehingga membentuk perilaku komunikasi yang ditampilkan

Kesimpulan yang didapat peneliti pada penelitian ini adalah pola komunikasi yang merupakan suatu pola aktivitas komunikasi yang berasal dari peristiwa komunikasi dalam keseharian, tindakan komunikasi dan situasi komunikasi, dengan begitu pola komunikasi terbentuk pada anak. Pola komunikasi terbentuk dari adanya pendidikan, harapan, aturan atau batasan, kebutuhan psikologis, pengawasan dan komunikasi antara ibu tunggal dan anak. Hal tersebut dilakukan melalui tindakan ibu tunggal pada anak dengan memberikan hukuman, nasehat, kasih sayang dan perlindungan. Menurut pengamatan peneliti semua itu dilakukan ibu tunggal ketika melihat atau mengekspresikan pola komunikasinya, kemudian seobjektif mungkin ibu tunggal melihat sesuai realita di lapangan, sesuai dengan pengalaman dan kehidupannya dalam menjalani kenyataan hidup apa adanya.

Perilaku ibu tunggal dalam pola komunikasi yang diterapkan, baik secara verbal dan non verbal, sehingga membentuk perilaku yang ditampilkan anak. Pada penelitian ini, temuan yang didapat peneliti pada perilaku yang ditampilkan anak yaitu anak jadi memiliki pemikiran yang dewasa, pengertian terhadap ibunya dan orang lain, memahami permasalahan, disiplin, mandiri, rajin beribadah, penyayang, patuh, memiliki rasa aman, saling menghargai, berprestasi, mudah bergaul dan dapat membuat keputusan untuk dirinya sendiri. Kesimpulan didapat peneliti bedasarkan pengamatan di lapangan setelah beberapa hari melakukan pengamatan di tempat tinggal subyek 1 dan 2. Dari data pendukung yang ditemukan peneliti pada hasil wawancara, terdapat perilaku anak yang muncul berupa pemaknaan anak pada ibu yaitu patuh, memberi alasan jika tidak sepaham, merasa disayangi, selalu diskusi, selalu menceritakan semua apapun, selalu saling bantu, selalu ada bila dibutuhkan.

Gambar berikut adalah model pola komunikasi ibu sebagai orang tua tunggal yang didapat dari keseluruhan pertanyaan penelitian yang telah dianalisis. Berdasarkan pada empat pertanyaan penelitian yang dibuat peneliti, maka dapat dikemukakan bahwa (1) Pola komunikasi ibu tunggal sesuai dengan teori yang digunakan, ditemukan empat model yaitu Ibu sebagai orang tua tunggal menerapkan nilai-nilai melalui aturan, kedisiplinan dan norma, dalam mengekspresikan nilai-nilai pendidikan dalam keluarga dengan tujuan diharapkan anak dapat berperilaku disiplin, rajin beribadah, bangun pagi, giat belajar;(2) Realitas sosial objektif ibu sebagai orang tua tunggal dalam menetapkan pola komunikasi melalui pengetahuan berupa nasehat, harapan dan keinginan ibu tunggal, sehingga anak akan mengerti dan siap dalam menghadapi masalah dan menerima keadaan;(3) Pola komunikasi ibu sebagai orang tua tunggal dengan menunjukkan kasih sayang, perhatian, agar kebutuhan psikologis anak terpenuhi dengan cara memperhatikan, memeluk, rasa khawatir, rasa takut kehilangan dan berusaha untuk sering berkomunikasi sehingga diinternalisasi/dimaknakan anak;(4) Pola komunikasi ibu sebagai orang tua tunggal dalam mendidik, memberi pengawasan dan sering berkomunikasi, dapat membuat anak mengerti dan memahami bahwa ibadah itu wajib, mengetahui yang baik dan yang buruk, sangat dekat dengan keluarga, selalu bercerita, selalu berdiskusi dan selalu bersama, sehingga membentuk perilaku komunikasi yang ditampilkan.

Seperti gambar 5 pada gambar 
berikut, yang merupakan gabungan dari hasil temuan penelitian dari gambar temuan 1, 2, 3, 4 yaitu:

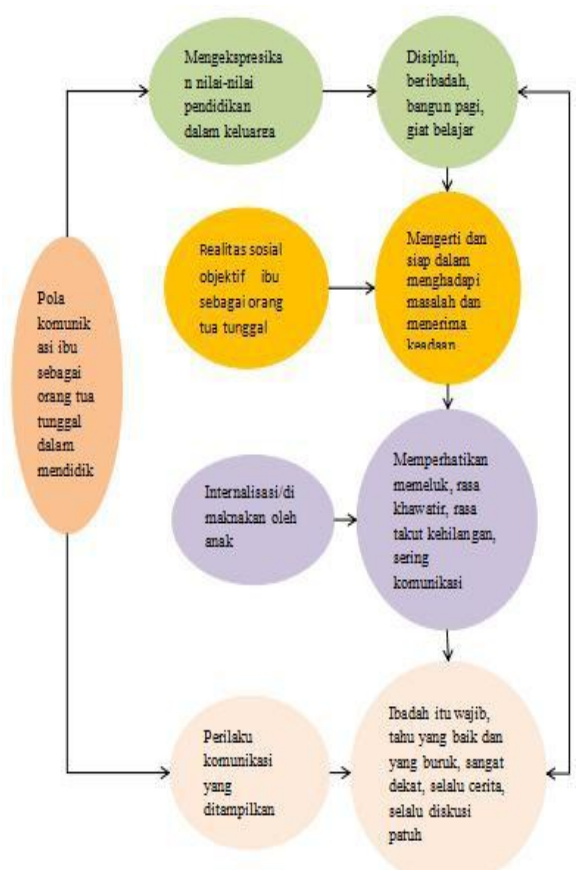

Gambar 5. Model Pola Komunikasi Ibu Tunggal

Berdasarkan penjelasan peneliti pada tahap analisis temuan penelitian, pola komunikasi terbentuk atas realitas sosial yang dikonstruksi oleh individu. Jika dikaitkan dengan teori konstruksi sosial dari Berger, suatu pemahaman dalam teori ini adalah realitas sosial yang dijelaskan dengan memisahkan dua istilah kunci, yakni "kenyataan" dan "pengetahuan". Kenyataan atau realitas adalah suatu kualitas yang terdapat dalam fenomena-fenomena yang diakui memiliki keberadaan (being)-nya sendiri sehingga tidak tergantung kepada kehendak manusia, sedangkan pengetahuan adalah kepastian bahwa fenomena-fenomena itu nyata (real) dan memiliki karakteristik yang spesifik.

Menurut peneliti, pola komunikasi ibu tunggal memiliki pemahaman pada kenyataan atau realitas yang terdapat dalam fenomena yang sesungguhnya yang apa adanya, sesuai dengan pertanyaan penelitian yang mengacu pada nilai-nilai pendidikan keluarga, aturan-aturan yang dibuat ibu tunggal adalah pembatas anak dalam melakukan sesuatu, anak diberi aturan agar dapat dipatuhi agar tidak keluar ketetapan yang dibuat dalam suatu keluarga, kemudian realitas sosial juga memiliki pengetahuan untuk dapat melihat masalah-masalah yang nyata. Ibu tunggal akan berusaha menanamkan norma-norma yang berlaku di dalam keluarga dengan dasar pendidikan berdasarkan kenyataan yang sebenarnya, agar anak-anak dapat menampilkan perilaku yang dapat membawanya diterima oleh lingkungan sosialnya. Hal ini terkait pula pada pertanyaan penelitian yang kedua, dimana realitas sosial objektif ibu tunggal dalam menerapkan pola komunikasi sesuai keadaannya. Ibu tunggal merasa mendidik anak-anak secara objektif adalah cara yang benar, sehingga ketika anak berbaur di lingkungan luar rumah, anak sudah menempa pengalaman terlebih dahulu di dalam keluarga. Pada pertanyaan penelitian yang ketiga adanya pemaknaan anak, dimana anak dididik untuk mengkonstruksi dirinya yang diinternalisasi.

Tiga hal ini berjalan secara simultan, artinya ada proses menarik keluar (ekternalisasi) sehingga seakanakan hal itu akan berada di luar (objektif) dan kemudian ada proses penarikan kembali kedalam (internalisasi) sehingga sesuatu yang berada di luar tersebut seakan-akan merupakan sesuatu yang berada di dalam diri. Keluarga adalah produk individu sehingga menjadi kenyataan objektif melalui proses eksternalisasi dan individu juga produk dari keluarga melalui proses internalisasi. Dalam penelitian ini, ibu sebagai orang tua tunggal berusaha untuk melakukan penyesuaian diri terhadap realitas sosial 
yang dihadapinya, komunikasi yang disampaikan pada anak dalam peristiwa keseharian yang berulang. Hal ini dilakukan seorang ibu tunggal agar terbentuk suatu pola komunikasi yang menampilkan suatu perilaku sesuai dengan yang diharapkan oleh seorang ibu tunggal.

Keterkaitan dengan teori ini jelas bahwa seorang ibu tunggal berusaha menanamkan perilaku melalui pendidikan yang diberikan pada anaknya, yaitu nilai-nilai, pengetahuan dan afeksi atau emosi, rasa nyaman dan aman, sehingga menghasilkan perilaku yang tampak dalam kehidupan sosialnya. Sesuai dengan penelitian terhadap subyek, tindakan yang dilakukan ibu adalah menanamkan nasehat-nasehat yang berguna bagi kehidupannya mendatang, menjaga perkataan dan perbuatan dengan memberikan contoh yang dilakukan oleh ibu, menanamkan nilai-nilai yang ada dalam masyarakat supaya anak dapat membawa diri dengan baik, dapat mengeyam bangku kehidupan dengan baik serta menjalankan ajaran agama dengan benar sebagai pedoman dalam kehidupan.

Tindakan yang dilakukan ibu didasarkan kasih sayang kepada anakanaknya dimana hanya memiliki ibu sebagai orang tua tunggal dapat menjadi pribadi yang baik pula, dengan begitu ibu mendapat penghargaan dari masyarakat bahwa seorang ibu dengan segala kesibukannya mampu membimbing dan mengarahkan anak dengan baik. Ibu ingin memberikan kesan yang baik untuk anak-anak sehingga anak-anakpun memberi respon yang baik, dimana dapat menjalani kehidupan dengan baik tanpa adanya ayah.

Dari beberapa penjelasan, salah satu masalah yang dihadapi oleh ibu orangtua tunggal adalah masalah finansial, terutama pada ibu yang dahulu sebagai ibu rumah tangga saja. Ada beberapa kasus perceraian salah satu orang tua yang setelah bercerai mengabaikan kewajibannya untuk memberikan nafkah hidup kepada anakanaknya. Kini ibulah yang harus menanggung total seluruh biaya untuk kebutuhan keluarga dan pengasuhan anak-anak. Hal ini sangat berat apabila ditanggung oleh seorang ibu, namun dengan adanya motivasi dari saudarasaudara, orang tua, sahabat dan anakanak membuat ibu menjadi termotivasi untuk terus berjuaang, tidak larut dalam kesedihan dan menjalankan perannya sebagai kepala keluarga serta dapat menjadi panutan bagi anak-anaknya.

Dalam keluarga dimana ibu sebagai orangtua tunggal menjalankan tuntutan untuk bekerja dan mampu menghadapi segala permasalahan dalam memenuhi kebutuhan diri dan anak- anaknya, maka ibu harus merasa yakin bahwa dirinya mampu dalam menghadapi tantangan baik merawat anak dan mencari nafkah hidup, setelah suami meninggal atau bercerai. Ibu sebagai kepala keluarga yang secara finansial dan sosial didukung dengan keberadaan ayah, setelah adanya perpisahan, perceraian atau kematian, ibu akan bekerja sebagai tulang punggung keluarga dan bertanggung jawab dalam perkembangan anak.

Keberhasilan dalam menyesuaikan diri akan membuat seseorang hidup dan bekerja dengan penuh semangat kebahagiaan serta terhindar dari kecemasan, kegelisahan dan kesedihan yang tidak perlu. Namun perlu diketahui bahwa tingkah laku seseorang akan berbeda satu dengan yang lainnya, karena hal ini dipengaruhi oleh kemampuan masing-masing individu dalam melakukan penyesuaian diri. Penyesuaian diri adalah sesuatu yang lekat ada pada manusia, karena pada dasarnya manusia cenderung selalu melakukan penyesuaian diri. 
Keluarga sebagai suatu sistem sosial yang penting dalam masyarakat. Perubahan dalam keluarga akan berkaitan erat perubahan peran dalam masyarakat, dengan terciptanya keseimbangan dalam keluarga, peranan yang dilaksanakan dengan penuh tanggung jawab sehingga keharmonisan keluarga dan keseimbangan dalam kehidupan bersama dapat tercipta.

Menurut Schneiders

(1964) penyesuaian diri timbul apabila terdapat kebutuhan, dorongan, dan keinginan yang harus dipenuhi oleh seseorang, termasuk juga saat seseorang menghadapi suatu masalah atau konflik yang harus diselesaikan. Individu pada kondisi ini individu akan mengalami proses belajar, belajar memahami, mengerti, dan berusaha untuk melakukan apa yang diinginkan oleh dirinya, maupun lingkungannya. Artinya, individu perlu mempertimbangkan adanya normanorma yang berlaku di lingkungan dalam memenuhi kebutuhannya. Hal ini dilakukan dengan tujuan untuk menyelaraskan pemuasan kebutuhan diri dengan situasi lingkungan sehingga tercapai suatu integrasi dan keseimbangan.

Ibu tunggal harus berusaha menyesuaikan diri dalam peran ganda, yakni peran ayah dan peran ibu, dengan demikian ibu tunggal harus dapat beradaptasi dan menyesuaikan diri, hal ini sesuai dengan teori penyesuaian diri, bahwa seorang ibu tunggal akan mengalami proses belajar, belajar memahami, mengerti dan berusaha untuk memenuhi kebutuhannya . Hal ini dilakukan ibu tunggal agar dapat bertahan dan mendidik anak dengan pola komunikasi yang baik, yang penuh dengan nilai-nilai pendidikan keluarga dan hidup bersama seorang ibu tunggal yang memiliki tujuan dan dapat mempertimbangkan norma-norma yang berlaku di lingkungan sosialnya. Untuk itu ibu selalu berusaha sebaik mungkin dalam menjalani peranan-peranan yang baru, mulai dari mencari nafkah, pendidikan anak dan ikut ambil bagian dalam kegiatan kemasyarakatan, dengan demikian ibu berhasil dalam menyesuaikan diri dengan peran dan fungsi yang baru sebagai kepala keluarga.

Pembahasan mengenai subyek penelitian, dapat terlihat pada hasil temuan peneliti yaitu pada saat observasi atau pengamatan ketika mengumpulkan kata kunci dari masingmasing subyek, terlihat bahwa diantara dua subyek memiliki karakter yang berbeda, pada subyek satu atau ibu Vie memiliki karakter baik, diam, ramah, sabar dan penyanyang dan pada subyek dua memiliki karakter semangat, pekerja keras, baik, perhatian, tegar dan tegas. Pada masing-masing karakter tersebut sesuai dengan tabel 4.1, jika peneliti dapat menyimpulkan bahwa subyek satu memiliki pola yang demokratis dan menuruti apa kemauan anak. Pada subyek dua terlihat bahwa ibu tunggal memiliki pola yang kearah disiplin yang kuat, sedikit otoriter namun pemerhati yang baik, sehingga dari keduanya dapat terlihat bahwa pola komunikasi ibu tunggal tidak pada satu pola, ada kecenderungan pola demokratis- permisif dan yang subyek dua pola otoriter-demokratis.

Perlakuan ibu tunggal subyek satu terlihat memanjakan anak, dan subyek dua dengan tegas dan pengawasan yang ketat memberikan kontrol yang kuat pada kedisiplinan anak. Menurut peneliti, berdasarkan hasil wawancara pada sumber terpercaya yaitu seorang psikolog perkembangan anak, bahwa konsep pengasuhan anak menjadi tidak jelas, jika ibu tunggal tidak konsisten dengan pola komunikasi yang dibuatnya (hasil wawancara Dian, Psikolog), sehingga 
jelas bahwa dari pola komunikasi yang ditemukan dalam hasil wawancara dan observasi, peneliti menganalisis adanya pola komunikasi yang tidak konsisten yang dilakukan ibu sebagai orang tua tunggal dalam mendidik anak. Namun tidak semua pola komunikasi tidak konsisten, karena subyek sebagai orang tua tunggal telah menerapkan disiplin yang baik pada anak, dengan perilaku anak yang patuh dan beribadah itu wajib, hal ini menjadi catatan bagi peneliti, bahwa dengan adanya aturan dan pengawasan serta kontrol yang seimbang, sehingga suatu pola komunikasi akan membentuk perilaku yang baik pada anak.

Hasil pembahasan yang dilakukan peneliti pada penelitian ini, dapat terlihat kaitan antara teori yang digunakan peneliti, teori-teori tersebut sangat berhubungan dengan keadaan ibu sebagai orang tua tunggal, seorang ibu tunggal akan mengkonstruksi apa yang dilihatnya pada lingkungan sekitar dan memaknai peran yang dijalaninya. Kemudian ibu sebagai orang tua tunggal dalam menjalankan peran sebagai ayah harus bisa menyesuaikan diri dengan keadaan yang dialaminya, agar ibu tunggal dapat menjalankan kehidupannya dengan baik baik secara fisik maupun psikis. Dan jika dilihat dari sisi positifnya, seorang ibu tunggal yang konsisten akan lebih bisa fokus dan bertanggung jawab atas tuntutan peran yang dijalaninya, sehingga dapat membentuk perilaku yang positif pada anak.

Seperti gambar 4.6 berikut, bahwa ibu tunggal membuat pola komunikasi berdasarkan atas pengalaman, pendidikan dan lingkungan dimana ibu tunggal berada. Suatu harapan atau keinginan ibu tunggal pada anak, dengan cara memberikan aturan dan nasehat melalui kebiasaan dan budaya keluarga yang akan membentuk perilaku.

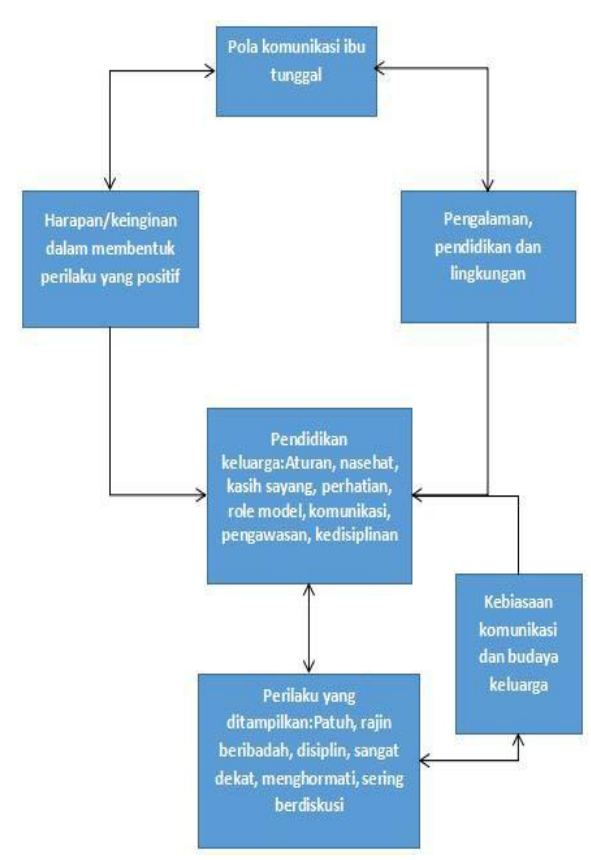

Gambar 6. Model Pola Komunikasi

Ibu Tunggal

\section{Simpulan dan Saran}

Berdasarkan analisis data dan pembahasan hasil penelitian tentang Pola Komunikasi Ibu sebagai Orang Tua Tunggal dalam Mendidik Anak. Peneliti dapat mengambil kesimpulan sebagai berikut:

1. Ibu sebagai orang tua tunggal menerapkan nilai-nilai melalui aturan, kedisiplinan dan norma, dalam mengekspresikan nilainilai pendidikan dalam keluarga dengan tujuan diharapkan anak dapat berperilaku disiplin, rajin beribadah, bangun pagi, giat belajar.

2. Realitas sosial objektif ibu sebagai orang tua tunggal dalam menetapkan pola komunikasi melalui pengetahuan berupa nasehat, harapan dan keinginan ibu tunggal, sehingga anak akan 


mengerti dan siap dalam
menghadapi masalah dan
menerima keadaan.

3. Pola komunikasi ibu sebagai orang tua tunggal dengan menunjukkan kasih sayang, perhatian, agar kebutuhan psikologis anakterpenuhi dengan cara memperhatikan, memeluk, rasa khawatir, rasa takut kehilangan dan berusaha untuk sering berkomunikasi sehingga diinternalisasi/dimaknakan anak.

4. Pola komunikasi ibu sebagai orang tua tunggal dalam mendidik, memberi pengawasan dan sering berkomunikasi, dapat membuat anak mengerti dan memahami bahwa ibadah itu wajib, mengetahui yang baik dan yang buruk, sangat dekat dengan keluarga, selalu bercerita, selalu berdiskusi dan selalu bersama, sehingga membentuk perilaku komunikasi yang ditampilkan.

Saran peneliti dalam penelitian pola komunikasi ibu sebagai orang tua tunggal dalam mendidik anak, yaitu:

1. Saran peneliti, penelitian ini dapat dilanjutkan dengan meneliti ibu tunggal muda yang memiliki anak usia balita, sehingga dapat terlihat pola komunikasi pada ibu tunggal muda yang masih memiliki anak berusia balita.

2. Saran peneliti, penelitian ini dapat dilanjutkan dengan melihat ibu tunggal dengan ekonomi menengah keatas, hal ini dimaksudkan peneliti agar penelitian yang selanjutnya dapat melihat kesulitan apa yang didapat oleh ibu tunggal dengan ekonomi yang menengah kebawah dalam memberikan pola komunikasi pada anak.

3. Saran peneliti, sebaiknya ibu tunggal memberikan pola komunikasi yang konsisten dalam mendidik anak, agar anak dapat memaknai pola komunikasi yang diberikan ibu tunggal, pola komunikasi yang konsisten yaitu yang tidak berubah-ubah agar anak dapat mengerti dan memahami keinginan ibu tunggal, sehingga dapat membentuk perilaku yang diharapkan.

4. Semoga penelitian ini dapat memberikan wawasan mengenai pola komunikasi ibu tunggal, sebab pola komunikasi dalam keluarga merupakan awal dari pendidikan dan awal dari pembentukan suatu perilaku anak, dimana perilaku tersebut menjadi cerminan budaya keluarga di masyarakat. Dengan harapan ibu sebagai orang tua tunggal dapat memberikan pola komunikasi yang baik dan menjadi contoh yang baik pula dalam mendidik anak.

5. Peneliti berharap penelitian ini dapat lebih membuka gagasan baru bagi penelitian selanjutnya mengenai pemaknaan anak pada pola komunikasi ibu tunggal, bagaimana anak merasakan, memahami, dan memaknai pola komunikasi ibu tunggal, dengan anak sebagai subyek dari penelitian.

\section{Daftar Pustaka}

Berger, Peter L \& Thomas luckman, 1966. Diterjemahkan oleh Basari, Hasan. 1990.Tafsir Sosial Atas Kenyataan: Sebuah Risalah Tentang Sosiologi Pengetahuan. Jakarta : LP3ES

Hurlock, Elizabeth B. 1980. Psikologi Perkembangan; Suatu Pendekatan 
Rentang Kehidupan. Jakarta:

Erlangga

Moleong, Lexy J. 2000. Metodologi

Penelitian Kualitatif. Bandung: Remaja

Rosdakarya

Ruben, Brent D \& Stewart, Lea P. Kata

Pengantar : Ibnu Hamad, 2013.

Komunikasi dan Perilaku

Manusia. Edisi Kelima. Jakarta :

Rajawali Pers.

Sutopo. $2000 . \quad$ Metode

Penelitian Kualitatif. Surakarta:

Sebelas Maret University Press

. 2002. Metodologi Penelitian Kualitatif.

Surakarta: Sebelas Maret University

Press 